\title{
DETECTION OF SALMONELLA SP IN CHICKEN CUTS USING IMMUNOMAGNETIC SEPARATION
}

\author{
Rita de Cássia dos Santos da Conceição ${ }^{1 *}$; Ângela Nunes Moreira ${ }^{2,3}$; Roberta Juliano Ramos ${ }^{3}$; \\ Fabiana Lemos Goularte ${ }^{3}$; José Beiro Carvalhal ${ }^{3}$; José Antonio Guimarães Aleixo ${ }^{2,3}$
}

${ }^{1}$ Faculdade de Veterinária, Universidade Federal de Pelotas, Pelotas, RS, Brasil; ${ }^{2}$ Centro de Biotecnologia, Universidade Federal de Pelotas, Pelotas, RS, Brasil; ${ }^{3}$ Faculdade de Nutrição, Universidade Federal de Pelotas, Pelotas, RS, Brasil.

Submitted: July 17, 2007; Returned to authors for corrections: October 17, 2007; Approved: January 20, 2008.

\begin{abstract}
The immunomagnetic separation (IMS) is a technique that has been used to increase sensitivity and specificity and to decrease the time required for detection of Salmonella in foods through different methodologies. In this work we report on the development of a method for detection of Salmonella in chicken cuts using in house antibody-sensitized microspheres associated to conventional plating in selective agar (IMS-plating). First, protein A-coated microspheres were sensitized with polyclonal antibodies against lipopolysacharide and flagella from salmonellae and used to standardize a procedure for capturing Salmonella Enteritidis from pure cultures and detection in selective agar. Subsequently, samples of chicken meat experimentally contaminated with $S$. Enteritidis were analyzed immediately after contamination and after $24 \mathrm{~h}$ of refrigeration using three enrichment protocols. The detection limit of the IMS-plating procedure after standardization with pure culture was about $2 \times 10 \mathrm{CFU} / \mathrm{mL}$. The protocol using non-selective enrichment for 6-8h, selective enrichment for 16-18h and a post-enrichment for $4 \mathrm{~h}$ gave the best results of $S$. Enteritidis detection by IMS-plating in experimentally contaminated meat. IMSplating using this protocol was compared to the standard culture method for salmonellae detection in naturally contaminated chicken cuts and yielded 100\% sensitivity and 94\% specificity. The method developed using in house prepared magnetic microespheres for IMS and plating in selective agar was able to diminish by at least one day the time required for detection of Salmonella in chicken products by the conventional culture method.
\end{abstract}

Key words: Salmonella, immunomagnetic separation, rapid methods.

\section{INTRODUCTION}

Salmonella still is the leading cause of foodborne infections all over the world (5). Transmission of Salmonella to humans is usually by consumption of undercooked meat, milk, eggs and other cross-contaminated foods, such as vegetables, that are eaten without cooking. Animal food products are the major responsible for the large distribution of salmonellae and all the subsequent problems. Meat products predominate among the animal foods considered source of salmonellae, especially those obtained from poultry $(12,16)$.
Conventional method used for Salmonella detection is timeconsuming, requiring 4 days for confirming negative results and 5-7 days for positive results (6). The long time for final results is due to various incubation periods used in this method for pre-enrichment, selective enrichment, colony isolation in selective and differential agar and biochemical and serological confirmation. To overcome this disadvantage, several rapid methods for the detection of Salmonella in foods have been developed to decrease the detection time. The immunomagnetic separation (IMS), that uses magnetic polystyrene microspheres coated with anti-Salmonella specific antibodies to capture the

*Corresponding Author. Mailing address: Faculdade de Veterinária, Universidade Federal de Pelotas, campus universitário, prédio 34, CEP 96010-900, Pelotas, RS, Brasil. Tel.: (53) 3275-7216. E-mail: ritac@ufpel.tche.br 
target cells, is a technique that has been proposed to replace or to improve the performance of the conventional selective enrichment of Salmonella $(4,7,11)$.

In this work the IMS was used to improve sensitivity and specificity and to decrease detection time of Salmonella in chicken cuts by the conventional culture method. To reach these objectives an in-house capture reagent was first prepared with commercially available protein A-coated magnetic polystyrene microspheres and anti-Salmonella polyclonal antibodies. After, the reagent was used to develop a method that combines IMS and conventional selective plating (IMS-plating) for detection of Salmonella in chicken products experimentally contamined. Finally, the performance of the IMS-plating method for detecting Salmonella in chicken products naturally contaminated was evaluated.

\section{MATERIALS AND METHODS}

\section{Bacterial strains and culture conditions}

Salmonella enterica subsp enterica serovar Enteritidis $(S$. Enteritidis) and Escherichia coli were obtained from the culture collection of FIOCRUZ (Rio de Janeiro, Brazil) and were grown in brain heart infusion broth (BHI, Difco, Detroit, USA) at $37^{\circ} \mathrm{C}$ for $24 h$.

\section{Magnetic microspheres and antibodies}

Protein A-covered magnetic polystyrene microspheres with $0.86 \mu \mathrm{m}$ diameter in $1 \%$ solids suspension (Bangs Laboratories, Fishers, IN, USA) were used. Polyvalent somatic and flagellar anti-Salmonella sera (PROBAC, São Paulo, Brazil) containing antibodies, respectively, against a common structural $\mathrm{O}$ antigen of groups A, B, C, D, E and against $\mathrm{H}$ antigens a, b, c, d, i, 1, 2, 5 , were used. The immunoglobulin $\mathrm{G}(\mathrm{IgG})$ from both sera was purified by affinity chromatography with protein A-Sepharose 4B resin, concentrated in a PEG $20 \%$ solution and dialyzed against $50 \mathrm{mM}$ sodium borate ( $\mathrm{pH}$ 8.2). Purity of IgG preparations was evaluated by SDS-PAGE and protein concentration determined by UV at $280 \mathrm{~nm}$ using 1.35 absorbance units as extinction coefficient $(1 \mathrm{mg} / \mathrm{mL})(7)$.

\section{Sensitization of microspheres with polyclonal antibodies}

Magnetic microspheres at a concentration of $1 \mathrm{mg} / \mathrm{mL}$ were washed twice with borate buffer $(50 \mathrm{mM}, \mathrm{pH} 8,2)$ using a magnet (MPC-S, Dynal, Norway). After washing, microspheres were suspended in one volume of borate buffer containing $0.6 \mathrm{mg} / \mathrm{mL}$ of purified $\mathrm{IgG}$ and incubated at $4^{\circ} \mathrm{C}$ for 16-18 hours. Sensitized microspheres were washed three times with borate buffer, suspended at $1 \%$ solids in stock buffer (borate buffer $10 \mathrm{mM}, \mathrm{pH} 8.5+0.01 \% \mathrm{BSA}+0.05 \%$ Tween 20 $+10 \mathrm{mM}$ EDTA $+0.1 \% \mathrm{NaN}_{3}$ ) and stored at $4^{\circ} \mathrm{C}(2)$. The microspheres were six fold diluted in stock buffer before using in IMS. Efficiency of IgG binding was determined indirectly from the amount remaining in the supernatant after the sensitization procedure. Sensitized microspheres were further observed under microscope to investigate the degree of autoagglutination and the agglutination behaviour with $S$. Enteritidis and E. coli cells. Batchs of microspheres with IgG reactive against somatic and flagella antigens were prepared separately.

\section{Standardization of IMS using Salmonella in pure culture}

$S$. Enteritidis was grown in $\mathrm{BHI}$ (Difco) at $37^{\circ} \mathrm{C}$ for $24 \mathrm{~h}$ and ten fold serial diluted to $10^{-9}$ with $0.1 \%$ peptone water. Aliquots $(1 \mathrm{~mL})$ of each dilution were incubated separately with different volumes $(5,10$ e $20 \mu \mathrm{L})$ of each type of microsphere in eppendorf tubes at room temperature for 15 minutes with constant agitation. The microspheres were exposed for 3-5 minutes to a magnetic concentrator (MPC-S, Dynal), the supernatant was removed by aspiration and the microspheres-antigen complex was suspended in $1 \mathrm{~mL}$ of phosphate-buffered saline with $0,05 \%$ de Tween 20 (PBST, $0.15 \mathrm{M}$ sodium chloride, $0.01 \mathrm{M}$ sodium phosphate, $\mathrm{pH} 7.4$ ). After repeating this washing procedure three times the microspheres were suspended in $20 \mu \mathrm{L}$ of sterile PBS, streaked onto XLD and incubated at $37^{\circ} \mathrm{C}$ for $24 \mathrm{~h}$ to observe growth of typical colonies. The experiment was carried out in triplicate with each volume of microsphere tested. The actual number of Salmonella in BHI culture was determined by plating decimal dilutions onto plate count agar plates (PCA, Merck, Darmstadt, Germany).

\section{Salmonella enrichment protocol}

To select an enrichment protocol (EP) for providing an adequate number of Salmonella in chicken meat for detection by IMS-plating, samples of ground meat $(25 \mathrm{~g})$ were inoculated with $S$. Enteritidis at different levels (1-10, 10-100, 100-1000 CFU), estimated by plating in PCA as above, and submitted to the following EP immediately after contamination and after $24 \mathrm{~h}$ of refrigeration at $4^{\circ} \mathrm{C}$ : (EP1) non-selective enrichment in lactose broth for $16-18 \mathrm{~h}$ at $37^{\circ} \mathrm{C}$; (EP2) lactose broth for $6-8 \mathrm{~h}$ at $37^{\circ} \mathrm{C}$, followed by selective enrichment in tetrathionate broth (TT) and Rappaport Vassiliadis broth (RV) for $16-18 \mathrm{~h}$ at $42^{\circ} \mathrm{C}$; (EP3) lactose broth for $6-8 \mathrm{~h}$ at $37^{\circ} \mathrm{C}$, followed by selective enrichment in TT broth and RV broth for $16-18 \mathrm{~h}$ at $42^{\circ} \mathrm{C}$ and a postenrichment in BHI for $4 \mathrm{~h}$ at $37^{\circ} \mathrm{C}$. At the end of each EP, $20 \mu \mathrm{L}$ of mixed microspheres against somatic and flagellar Salmonella antigens was added to $1 \mathrm{~mL}$ of enrichment broth for IMS and plating as described before (item 4). Suspected salmonellae colonies growing onto selective agar were confirmed by biochemical and serological tests. The experiment was repeated three times with each EP and contamination level. A noninoculated sample of the chicken meat was included in each repeat to certify that the meat was free from naturally occurring Salmonella. 
Evaluation of IMS-plating for detection of Salmonella in naturally contaminated chicken cuts.

This experiment was performed with 80 chicken cuts (upper thigh, drummette, ground meat and liver) obtained in packages of approximately $0.3 \mathrm{Kg}$ from local supermarkets. Sampling of upper thighs and drummettes was made by rinsing the entire package content with $300 \mathrm{~mL}$ of lactose broth (CL, Merck, Darmstadt, Germany) in sterile plastic bags, while for ground meat and liver $25 \mathrm{~g}$ samples were weighed in sterile plastic bags and homogenized with $225 \mathrm{~mL}$ of CL in a Stomacher ${ }^{\circledR}$ (Thetford, Norfolk, UK). Following the sampling procedure the samples of chicken cuts were submitted to EP3 for detection of salmonellae by IMS and plating onto XLD and BPLS agar with novobiocin $(10 \mu \mathrm{g} / \mathrm{mL})$ and, for comparison purposes, to conventional enrichment for detection by the standard culture method (6).

\section{Sensitivity and specificity analysis}

The results obtained in this experiment were used to calculate the sensitivity (positive samples in the IMS also positive in the conventional methodology) and specificity (negative samples in the IMS also negative in the conventional methodology).

\section{RESULTS AND DISCUSSION}

Microspheres were successfully sensitized with affinity purified polyvalent IgG against somatic and flagella antigens. Approximately $50 \%$ of the $\mathrm{IgG}$ used for sensitization remained bound to microspheres, and a scanty auto-agglutination and specific agglutination with $S$. Enteritidis cells and no agglutination with Escherichia coli cells were observed (data not shown).

An experiment to determine the adequate volume of sensitized microspheres for use in IMS was carried out using a pure culture of $S$. Enteritidis (Table 1). The two types of microspheres were tested, using three different volumes, and the detection limit of the IMS procedure was approximately 20 $\mathrm{UFC} / \mathrm{mL}$ for both. This detection limit was similar to that found in other IMS studies with Salmonella (11) and other bacteria such as Actinobacillus pleuropneumoniae and Pasteurella multocida (1) and was better than the $10^{3} \mathrm{UFC} / \mathrm{mL}$ found for Campylobacter jejuni (17).

A direct relationship between the quantity of microspheres used for IMS and the detection limit was not observed. The results have shown that even in the smallest volume $(5 \mu \mathrm{L})$ used there was an adequate amount of microspheres for capturing $S$. Enteritidis from a pure culture suspended in peptone water. However, this amount could not be sufficient when the target organism is to be separated from enrichment broth containing natural flora and food constituents $(4,10)$. Polyvalent antibodies used in microsphere sensitization, specially the antiLPS antibodies, can cross-react with other enterobacteria from
Table 1. Performance of different volumes of microspheres sensitized with somatic and flagellar antibodies in the recovery of Salmonella Enteritidis from pure cultures.

\begin{tabular}{ccccccc}
\hline & \multicolumn{6}{c}{ Microsphere volumes } \\
\cline { 2 - 7 } Dilutions & \multicolumn{2}{c}{$5 \mu \mathrm{L}$} & \multicolumn{2}{c}{$10 \mu \mathrm{L}$} & \multicolumn{2}{c}{$20 \mu \mathrm{L}$} \\
\cline { 2 - 7 } & $\mathrm{S}$ & $\mathrm{F}$ & $\mathrm{S}$ & $\mathrm{F}$ & $\mathrm{S}$ & $\mathrm{F}$ \\
\hline $10^{-3}$ & $\mathbf{3 / 3}$ & $\mathbf{3 / 3}$ & $\mathbf{3 / 3}$ & $\mathbf{3 / 3}$ & $\mathbf{3 / 3}$ & $\mathbf{3 / 3}$ \\
$10^{-4}$ & $\mathbf{3 / 3}$ & $\mathbf{3 / 3}$ & $\mathbf{3 / 3}$ & $\mathbf{3 / 3}$ & $\mathbf{3 / 3}$ & $\mathbf{3 / 3}$ \\
$10^{-5}$ & $\mathbf{3 / 3}$ & $\mathbf{3 / 3}$ & $\mathbf{3 / 3}$ & $\mathbf{3 / 3}$ & $\mathbf{3 / 3}$ & $\mathbf{3 / 3}$ \\
$10^{-6}$ & $\mathbf{3 / 3}$ & $\mathbf{3 / 3}$ & $\mathbf{3 / 3}$ & $\mathbf{3 / 3}$ & $\mathbf{3 / 3}$ & $\mathbf{3 / 3}$ \\
$10^{-7}$ & $\mathbf{3 / 3}$ & $\mathbf{3 / 3}$ & $\mathbf{3 / 3}$ & $\mathbf{3 / 3}$ & $\mathbf{3 / 3}$ & $\mathbf{3 / 3}$ \\
$10^{-8}$ & $\mathbf{2 / 3}$ & $\mathbf{3 / 3}$ & $\mathbf{3 / 3}$ & $\mathbf{2 / 3}$ & $\mathbf{3 / 3}$ & $\mathbf{2 / 3}$ \\
$10^{-9}$ & $\mathbf{0 / 3}$ & $\mathbf{0 / 3}$ & $\mathbf{0 / 3}$ & $\mathbf{0 / 3}$ & $\mathbf{0 / 3}$ & $\mathbf{0 / 3}$ \\
\hline
\end{tabular}

${ }^{a}$ positive recovery /repeats; S: somatic antibodies; F: flagellar antibodies; Initial count: 2 x $10^{9} \mathrm{CFU} / \mathrm{mL}$.

chicken meat thus lowering the number of sites available for Salmonella binding. For this reason, and to increase the panel of antibodies capable of binding Salmonella antigens, a decision was made to use in IMS a mixture of equal parts $(10 \mu \mathrm{L})$ of the microspheres sensitized with $\operatorname{IgG}$ against somatic or flagella antigens.

Performance of different EP associated to IMS-plating for detection of $S$. Enteritidis in samples of chicken meat experimentally contaminated is shown in Table 2. Three independent experiments were carried out using three levels of

Table 2. Performance of the different enrichment protocols ${ }^{\mathrm{a}}$ used for detection of Salmonella Enteritidis in chicken meat experimentally contaminated.

\begin{tabular}{ccccccccc}
\hline $\begin{array}{c}\text { Contamination } \\
\text { level (CFU/25g) }\end{array}$ & \multicolumn{3}{c}{$\begin{array}{c}\text { Immediately after } \\
\text { contamination }\end{array}$} & \multicolumn{4}{c}{$\begin{array}{c}\text { After 24h of } \\
\text { refrigeration }\end{array}$} \\
\cline { 2 - 9 } & EP1 & EP2 & EP3 & EP1 & EP2 & EP3 \\
\cline { 2 - 8 } & \multicolumn{3}{c}{$\mathbf{R V}^{\mathrm{b}}$} & TT $^{\mathrm{b}}$ & & & RV & TT \\
\hline $\mathbf{0 - 1 0}$ & $1 / 3^{\mathrm{c}}$ & $2 / 3$ & $2 / 3$ & $3 / 3$ & $0 / 3$ & $0 / 3$ & $0 / 3$ & $2 / 3$ \\
$\mathbf{1 0 - 1 0 0}$ & $3 / 3$ & $2 / 3$ & $3 / 3$ & $3 / 3$ & $0 / 3$ & $1 / 3$ & $0 / 3$ & $1 / 3$ \\
$\mathbf{1 0 0 - 1 0 0 0}$ & $2 / 3$ & $2 / 3$ & $3 / 3$ & $3 / 3$ & $0 / 3$ & $1 / 3$ & $0 / 3$ & $1 / 3$ \\
\hline
\end{tabular}

${ }^{\text {a }}$ EP1 (Enrichment Protocol 1) = lactose broth (16-18 h), IMS and plating; EP2 (Enrichment Protocol 2) = lactose broth (6-8h), selective enrichment in TT and RV (16-18h), IMS in TT and RV and plating; EP3 (Enrichment Protocol 3) = lactose broth $(6-8 \mathrm{~h})$, selective enrichment in TT and RV (16-18h), post-enrichment of TT+RV in BHI (4h), IMS and plating.

${ }^{\mathrm{b}} \mathrm{RV}=$ Rappaport-Vassiliadis broth; TT=Tetrathionate broth

${ }^{\mathrm{c}}$ Positive samples /repeats. 
$S$. Enteritidis contamination and samples were analysed immediately after contamination and after $24 \mathrm{~h}$ of refrigeration. $S$. Enteritidis was detected immediately after meat contamination, in every level of contamination, by the enrichment protocols tested. However, after $24 \mathrm{~h}$ of refrigeration only EP3 was able to detect $S$. Enteritidis at the lowest level of contamination tested (1-10 CFU/25g), while EP1 and EP2 yielded unsatisfactory results. Since the best result was obtained with EP3, this protocol was chosen for association with IMS-plating in the study of Salmonella detection in naturally contaminated chicken cuts.

Our attempt to substitute selective enrichment by using IMS directly in the non-selective enrichment broth (EP1) was not successful. Previous attempts of reducing analysis time of conventional Salmonella detection methodology by using IMS after the non-selective enrichment of several types of foods were also unsuccessful $(10,14)$. These results point out the importance of the enrichment step in novel methodologies for detection of salmonellae in foods. Besides being present in a few number, Salmonella cells can be injuried during storage or processing of foods so that they will need an incubation time in a rich liquid broth to recover the capacity to grow onto selective agar plates. A study by Skjerve and Olsvik (15), suggest that at least 500 Salmonella cells must be originally present in a $25 \mathrm{~g}$ sample of food to obtain an isolated colony in selective agar after IMS and plating directly from non-selective enrichment broth.

Another factor influencing growth of isolated Salmonella colonies is the presence in the enrichment broth of cross-reacting mucoid bacteria that bind to microspheres coated with polyclonal antibodies. Cudjoe and Krona (3), reported that growth of mucoid colonies of Proteus spp and coliforms such as Escherichia coli, Klebsiella aerogenes and Enterobacter spp, impairs isolation of salmonellae in selective agar after IMS. The same problem came out in this work and was resolved in part by adding novobiocin to plating media as suggested by others (11). Even with the antibiotic in it the selective agar still allowed growth of suspect colonies of Salmonella that were not confirmed in the biochemical and serological testing.

IMS-plating detected Salmonella in 7 out of $80(8.7 \%)$ chicken cuts, while conventional methodology detected the bacterium in only $2(2.5 \%)$ (Table 3$)$. The two samples detected by conventional methodology were also detected by IMSplating. Positive Salmonella isolates were subsequently serotyped by FIOCRUZ (Rio de Janeiro, Brazil). Six isolates $(85.7 \%)$ were serotyped as Salmonella Enteritidis and one (14.3\%) was Salmonella Derby.

The good performance of the IMS-plating method is consistent with previous results, which found IMS associated to plating on selective agar better than conventional culture method for salmonellae detection $(3,8,9,15)$. In contrast, other studies have reported a poor performance of the method that combines IMS with plating on selective agar for Salmonella
Table 3. Comparison of IMS-plating with conventional methodology for Salmonella detection in chicken cuts.

\begin{tabular}{ccc}
\hline Chicken cuts & IMS-plating & $\begin{array}{c}\text { Conventional } \\
\text { methodology }\end{array}$ \\
\hline Upper thighs & $0 / 20^{*}$ & $0 / 20$ \\
Drummettes & $0 / 20$ & $0 / 20$ \\
Liver & $0 / 20$ & $0 / 20$ \\
Ground meat & $7 / 20$ & $2 / 20$ \\
\hline Total & $\mathbf{7 / 8 0}$ & $\mathbf{2 / 8 0}$ \\
\hline
\end{tabular}

*Positive samples/Tested samples.

detection in chicken samples $(13,14)$. The use of different enrichment protocols before IMS can be the cause of such contrasting results, since it is well known that selective agents of enrichment broths and incubation time and temperature are factors that affect decisively the analysis outcome (6).

The IMS-plating method developed in this study did not allow bypassing the biochemical and serological confirmation steps of conventional methodology because several of the colonies growing on agar were not confirmed as Salmonella. Among the 80 samples of chicken products analyzed about $90 \%(72 / 80)$ and $28 \%(22 / 80)$ presented suspected colonies on selective agar in the conventional methodology and IMS-plating method, respectively. In the latter method isolates from only 7 samples were confirmed as Salmonella, suggesting that the antibodies used for capture were not specific and that novobiocin used on selective agar to inhibit Proteus sp was not efficient to inhibit other enterobacteria. Even though our IMS-plating method did not avoid confirmation of suspected colonies it still allows reducing detection time by $24 \mathrm{~h}$ compared to conventional methodology, a result also found by others $(3,10)$. Associating IMS to rapid and sensitive methods such as ELISA is the preferred approach to reduce Salmonella detection time while increasing specificity. Recently, an ELISA performed after an enrichment protocol similar to that used in the present study (EP3) was able to detect Salmonella in chicken meat within 27 hours (11).

\section{RESUMO}

\section{Detecção de salmonella sp em cortes de frango usando separação imunomagnética}

A separação imunomagnética (IMS) é uma técnica que tem sido associada a diferentes métodos de detecção de Salmonella em alimentos para aumentar a sensibilidade e a especificidade e diminuir o tempo de análise. Neste trabalho é comunicada a obtenção de microesferas magnéticas sensibilizadas com anticorpos anti-Salmonella e seu uso em associação com a 
metodologia de cultivo convencional para desenvolver um método de detecção de salmonelas em cortes de frango (IMSplaqueamento). Inicialmente, microesferas cobertas com proteína A foram sensibilizadas com anticorpos policlonais contra lipopolissacarídeo e flagelo de salmonelas e usadas na padronização de um procedimento que captura Salmonella Enteritidis em cultivo puro e faz posterior detecção em ágar seletivo. A seguir, amostras de carne de frango experimentalmente contaminadas com $S$. Enteritidis foram analisadas imediatamente após a contaminação e após $24 \mathrm{~h}$ de refrigeração utilizando três protocolos de enriquecimento. $\mathrm{O}$ limite de detecção foi cerca de 2x10 UFC/mL. O protocolo que incluiu enriquecimento não-seletivo por 6-8h, enriquecimento seletivo por $16-18 \mathrm{~h}$ e pós-enriquecimento por $4 \mathrm{~h}$ foi o que proporcionou melhor resultado na detecção de $S$. Enteritidis em carne de frango experimentalmente contaminada. Este protocolo foi comparado à metodologia convencional em estudo de detecção de salmonelas em cortes de frango naturalmente contaminados e obteve $100 \%$ de sensibilidade e $94 \%$ de especificidade. O método desenvolvido foi capaz de diminuir em pelo menos um dia o tempo de detecção de salmonelas em cortes de frango pela metodologia convencional.

Palavras-chave: Salmonella, separação imunomagnética, métodos rápidos.

\section{REFERENCES}

1. Angen, O.; Heegaard, P.M.H.; Lavritsen, D.T.; Sorensen, V. (2001) Isolation of Actinobacillus pleuropneumoniae serotype 2 by immunomagnetic separation. Vet. Microbiol., 79: 19-29.

2. Bangs Laboratories. (1999). Technote 101 - Proactive microspheres, 7

3. Cudjoe, K.S.; Krona, R. (1997). Detection of Salmonella from raw food samples using Dynabeads anti-Salmonella and a convencional reference method. Int. J. Food Microbiol., 37: 55-62.

4. Cudjoe, K.S.; Krona, R.; Olsen, E. (1994). IMS: a new selective enrichment technique for detection of Salmonella in foods. Int. J. Food Microbiol., 23: 159-165.
5. D‘Aoust, J.; Maurer, J.; Bailey, J.S. (2001). Salmonella species. In: Doyle, M.P.; Beuchat, L.R.; Montville, T.J. (eds). Food microbiology: fundamental and frontiers. ASM, 2th ed., Washington, p.141- 77.

6. FDA. Salmonella. Bacteriological analytical manual online. Chapter 5, 2006. Disponível em: <http://www.cfsan.fda.gov/ ebam/bam5.html >. Acesso em: 12 jun. 2006.

7. Harlow, E.; Lane, D. (1988). Antibodies, a laboratory manual. Cold Spring Harbor Laboratory, Cold Spring Harbor, New York, 726p.

8. Lynch, M.J.B.; Leon-Velarde, C.G.; McEwen, S.; Odumeru, J.A (2004). Evaluation of an automated immunomagnetic separation method for the rapid detection of Salmonella species in poultry environmental samples. J. Microbiol. Methods, 58: 285-288.

9. Mansfield, L.; Forsythe, S.J. (1993). Immunomagnetic separation as an alternative to enrichment broths for Salmonella detection. Lett. Appl. Microbiol., 16: 122-125.

10. Mansfield, L.; Forsythe, S. (1996). Collaborative ring-trial of Dynabeads anti-Salmonella for immunomagnetic separation of stressed Salmonella cells from herbs and spices. Int. J. Food Microbiol., 29: 41-47.

11. Mansfield, L.P.; Forsythe, S.J. (2001). The detection of Salmonella serovars from animal feed and raw chicken using a combined immunomagnetic separation and ELISA method. Food Microbiol., 18: 361-366.

12. Peresi, J.T.M.; Lima, I.A.Z.C.; Tavechio, A.T; Fernandes, S.A.; Gelli, D.S. (1999). Salmonella: determinação de sorotipos e resistência a agentes microbianos de cepas isoladas de carcaças de frango comercializadas na região de São José do Rio Preto-SP. Rev. Inst. Adolfo Lutz, 58: 41-6.

13. Ribeiro, A.R.; Nascimento, V.L.; Cardoso, M.O.; Santos, L.R.; Rocha, S.S. (2002). Utilization of imunomagnetic separation for detection of Salmonella in raw broiler parts. Braz. J. Microbiol., 33: 339-341.

14. Ripabelli, G.; Sammarco, M.L.; Ruberto, A.; Lannitto, G.; Grasso, G.M. (1997). Immunomagnetic separation and conventional culture procedure for detection of naturally occurring Salmonella in raw pork sausages and chicken meat. Lett. Appl. Microbiol., 24: 493497.

15. Skjerve, E.; Olsvik, O. (1991). Immunomagnetic separation of Salmonella from foods. Int. J. Food Microbiol., 14: 11-18.

16. Sumner, J.; Raven, G.; Givney, R. (2004). Have changes to meat and poultry food safety regulation in Australia affected the prevalence of Salmonella or of salmonellosis? Int. J. Food Microbiol., 92(2): 199-205.

17. Yu, L.S.L.; Uknalis, J.; Tu, S. (2001). Immunomagnetic separation methods for the isolation of Campylobacter jejuni from ground poultry meats. J. Immunol. Methods, 256: 11-18. 